\title{
Bradykinin-induced Changes in Phosphatidyl Inositol Turnover in Cultured Rabbit Papillary Collecting Tubule Cells
}

\author{
James A. Shayman and Aubrey R. Morrison \\ Departments of Medicine and Pharmacology, Washington University Medical School, St. Louis, Missouri 63110
}

\begin{abstract}
Rabbit renal papillary collecting tubule cells were isolated as a homogenous population and grown in primary culture. These cells were maintained in fully defined medium to inhibit fibroblast overgrowth and to facilitate labeling of endogenous inositol phospholipids with myo- $\left[2-{ }^{3} \mathrm{H}\right]$ inositol with high specific activity. These cells demonstrated the morphology, cyclic AMP responsiveness, and prostaglandin $\mathbf{E}_{2}\left(\mathrm{PGE}_{2}\right)$ elaboration, consistent with previous published characterizations. When cells labeled with myo- $\left[2-{ }^{3} \mathbf{H}\right]$ inositol were stimulated by bradykinin at $10^{-7}$ $\mathbf{M}$, time-dependent and reversible changes in the distribution of inositol polyphosphates were observed. Inositol 1,4,5-triphosphate and inositol 1,4-diphosphate showed time-dependent and dose-dependent increases to maximal levels of 225 and $223 \%$ of control, respectively. These data indicate that the elaboration of inositol polyphosphates is a biochemical correlate to bradykinin stimulation and may play a role in $\mathbf{P G E}_{2}$ release in renal papillary collecting tubule cells.
\end{abstract}

\section{Introduction}

With the development of techniques for isolation and appropriate medium for propagation, the study of renal metabolism through the utilization of primary cultures has become practical. Distal tubular epithelia, in particular, serves as an interesting model system for the study of renal prostaglandin $\mathrm{E}_{2}\left(\mathrm{PGE}_{2}\right)^{1}$ elaboration and its interaction with other effectors known to exert physiological effects at this site in the nephron. Several observations support this view. First, $\mathrm{PGE}_{2}$ inhibits vasopressin-induced cyclic AMP (cAMP) formation in intact cells (1-4), but in and of itself, $\mathrm{PGE}_{2}$ may induce cAMP formation (3-5). Second, bradykinin (BK), a known inducer of $\mathrm{PGE}_{2}$ formation (6), may negatively modulate vasopressin action (7). In other tissues, for example, comparable kinin concentrations induce prostaglandin-dependent changes in short-circuit current and chloride

Address correspondence to Dr. Morrison, Department of Pharmacology.

Received for publication 25 October 1984 and in revised form 29 April 1985.

1. Abbreviations used in this paper: AVP, arginine vasopressin; BK, bradykinin; DME, Dulbecco's modified Eagle's medium; GPI, glyceryl phosphatidyl inositol; GPI4P, glyceryl phosphatidyl inositol 4 monophosphate; GPI4,5P $\mathrm{P}_{2}$, glyceryl phosphatidyl inositol 4,5 bisphosphate; IBMX, isobutylmethylxanthine; iPGE $_{2}$, immunoreactive prostaglandin $E_{2}$; ICP, inositol 1,2 cyclic phosphate; $I, 4 P_{2}$, inositol 1,4 diphosphate; I1P, inositol 1 phosphate; $I 1,4,5 \mathrm{P}_{3}$, inositol $1,4,5$ triphosphate; PI, phosphatidyl inositol; PI4P, phosphatidyl inositol 4 monophosphate; PI 4,5 $\mathrm{P}_{2}$, phosphatidyl inositol 4,5 bisphosphate; RPCT, renal papillary collecting tubule.

J. Clin. Invest.

(c) The American Society for Clinical Investigation, Inc. 0021-9738/85/09/0978/07 \$1.00

Volume 76, September 1985, 978-984 transport $(8,9)$. Third, distal tubular epithelia demonstrate polarity in response to $\mathrm{BK}$-induced $\mathrm{PGE}_{2}$ stimulation (10).

Although the interactive roles of arginine vasopressin (AVP), $\mathrm{BK}$, and $\mathrm{PGE}_{2}$ have been the object of significant recent study, the precise manner in which $\mathrm{BK}$ induces its effect in renal tissue has not. In considering how BK binding might be transduced as a signal, it is reasonable to investigate the role of phosphatidyl inositol and its congeners. BK, for example, induces PG formation in fibroblasts (11) and has been associated with degradation of phosphatidyl inositol in a fibrosarcoma cell line (12). The association of BK stimulation with formation of polyphosphoinositides remains uninvestigated in renal epithelia. Finally, other effectors induce phosphatidyl inositol turnover in the kidney $(13,14)$.

We report the characterization and labeling of primary cultures of rabbit renal papillary collecting tubule cells in the investigation of BK-stimulated PI turnover.

\section{Methods}

Materials. Myo-[2- $\left.{ }^{3} \mathrm{H}\right]$ inositol (specific activity, 10.2 and $16.5 \mathrm{Ci} / \mathrm{mmol}$ ) was purchased from Amersham Corp. (Arlington Heights, IL). [ $\left.{ }^{3} \mathrm{H}\right] \mathrm{PGE}_{2}$ was obtained from New England Nuclear (Boston, MA). ${ }^{125}$ I-succinyl cAMP was the generous gift of Dr. Kevin Martin, Washington University Medical School, St. Louis, MO. Cyclic AMP, $\mathrm{PGE}_{2}$, insulin, transferrin, sodium selenite, hydrocortisone, and triiodothyronine were purchased from Sigma Chemical Co. (St. Louis, MO). Dulbecco's modified Eagle's medium (DME) and Ham's F-12 medium both with and without inositol, were obtained from the Washington University Cancer Research Center (St. Louis, MO). Collagenase (type II) was purchased from Worthington Biochemical Corporation (Freehold, NJ). AG 1- $\times 8$ anion exchange resin $(200 \times 400$ mesh, formate form) was from Bio-Rad Laboratories (Richmond, CA). 24-well cell culture dishes were from Costar (Cambridge, MA).

Isolation of renal papillary collecting tubule (RPCT) cells. Cells were isolated and plated as previously described (6). In short, female New Zealand White rabbits $(2-3 \mathrm{~kg})$ were anesthetized with pentobarbital $(50$ $\mathrm{mg} / \mathrm{kg}$ ). The kidneys were resected and placed in cold phosphate-buffered saline. The papillae $(0.5-0.8 \mathrm{mg})$ were dissected free and minced with a sterile razor blade. The tissue mince was then incubated in Krebs solution $\left(37^{\circ} \mathrm{C}, \mathrm{pH} 7.3,10 \% \mathrm{CO}_{2}\right)$ and collagenase $(1 \mathrm{mg} / \mathrm{ml})$ for $90-120 \mathrm{~min}$. Thereafter, the digestate was filtered through stainless steel mesh (200 $\mu \mathrm{m})$ and diluted 1:2, vol/vol in distilled water. The cell suspension was pelleted at $500 \mathrm{~g}$ (TJ-6 centrifuge; Beckman Instruments, Inc., Fullerton, CA) for $5 \mathrm{~min}$, resuspended in phosphate-buffered saline, and repelleted. The final cell pellet was resuspended in the culture medium. Cells were plated at $\sim 5 \times 10^{4}$ cells $/ 16-\mathrm{mm}$ well.

Cell growth. Cells were grown without serum as previously described (15). This medium contained a mixture $1: 1$, vol/vol of Ham's F-12 and DME, insulin $(5 \mu / \mathrm{ml})$, hydrocortisone $\left(5 \times 10^{-8} \mathrm{M}\right)$, triiodothyronine $\left(5 \times 10^{-12} \mathrm{M}\right)$, penicillin $(50 \mathrm{U} / \mathrm{nl})$, strepomycin $(50 \mu \mathrm{l} / \mathrm{ml})$, Hepes $(10$ $\mathrm{mM}, \mathrm{pH} 7.4)$, and $\mathrm{NaH}_{2} \mathrm{CO}_{3}(1.1 \mathrm{mg} / \mathrm{ml}) . \mathrm{PGE}_{1}$ was not used and its absence had no discernable effect on growth. This medium has been shown previously to support the growth of renal tubular cells in primary culture (16). For studies involving arginine vasopressin (AVP)-induced cAMP formation or BK-induced immunoreactive prostaglandin $E_{2}$ 
$\left(\mathrm{iPGE}_{2}\right)$ release, inositol-replete medium was used. In experiments utilizing myo- $\left[2-{ }^{3} \mathrm{H}\right]$ inositol, inositol-free medium was used. All experiments were performed in confluent cultures averaging $35.6 \mu \mathrm{g}$ protein per well, representing $10^{5}$ cells.

Electron microscopy. Cells examined by electron microscopy were fixed while adherent to culture dishes as follows: $2.5 \%$ glutaraldehyde and sodium cacadylate buffer ( $\mathrm{pH}$ 7.2) were added for $1 \mathrm{~h}$. Cells were rinsed with $0.2 \mathrm{M}$ sodium cacadylate and post-fixed with $1 \%$ osmium tetroxide in $0.1 \mathrm{M}$ cacadylate for $1 \mathrm{~h}$. Samples were rinsed with water and subsequently block-stained with $0.5 \%$ uranyl acetate for $1 \mathrm{~h}$ and dehydrated with a graded series of ethanol. The cells were finally embedded in Polybed 812 resin (Polyscience Corp., Niles, IL) and studied under a Phillip 201 electron microscope.

CAMP and $i P G E_{2}$ radioimmunoassay (RIA). The measurement of intracellular cAMP was performed as follows. Cells were incubated in Krebs solution at $37^{\circ} \mathrm{C}, 10 \% \mathrm{CO}_{2}$ with or without effectors. After the appropriate incubation time, the supernatant was aspirated and $500 \mu \mathrm{l}$ of $\mathrm{H}_{2} \mathrm{O}\left(90-100^{\circ} \mathrm{C}\right)$ was added. The cell lysate was divided in half. To one fraction $100 \mu \mathrm{l}$ of $0.5 \%$ sodium dodecyl sulfate (SDS) was added to solubilize the protein; on the other fraction the CAMP RIA was performed. The RIA protocols for cAMP $(17,18)$ and $\operatorname{iPGE}_{2}(13)$ have been described elsewhere. $\mathrm{PPGE}_{2}$ was assayed from the supernatant of cells incubated with Krebs solution with or without effectors. To the adherent cells 200 $\mu \mathrm{l}$ of $0.5 \%$ SDS was added for $1 \mathrm{~h}$. Protein concentration was assayed by the method of Lowry (19).

Cell labeling, incubation, and extractions. After cells were grown to confluence, myo- $\left[2-{ }^{3} \mathrm{H}\right]$ inositol at $4 \mu \mathrm{Ci}$ per well was added to cells grown in inositol-free medium. Typically, 5-10\% of total label added was incorporated into cell extracts. Steady-state labeling occurred by $24 \mathrm{~h}$, consistent with previous observations (20). For experiments investigating BK-induced PI turnover, cells were washed four times with Krebs buffer $\left(37^{\circ} \mathrm{C}\right)$ and subsequently exposed to $\mathrm{BK}\left(10^{-7} \mathrm{M}\right)$ for variable times. After exposure, the incubation was terminated by aspiration of the supernatant and the addition of $250 \mu \mathrm{l}$ ice-cold acidified methanol $(2.4 \mathrm{~N}$ $\mathrm{HCl})$. Cells were scraped from the wells and the wells were rewashed with an equal volume of methanol. To this extract $500 \mu \mathrm{l}$ of chloroform and $500 \mu \mathrm{l}$ of $\mathrm{H}_{2} \mathrm{O}$ were added. The solution was vortexed and separated by centrifugation ( $500 \mathrm{~g}$ for $5 \mathrm{~min}$ ). The interface and upper phase were rewashed with $1 \mathrm{cc}$ chloroform and reseparated. The upper aqueous phase was separated and saved for future analysis. To the organic phase $500 \mu \mathrm{l}$ of $1 \mathrm{~N} \mathrm{NaOH}$ in methanol/water $(19: 1, \mathrm{vol} / \mathrm{vol})$ was added. After $20 \mathrm{~min}$ at $25^{\circ} \mathrm{C}, 1 \mathrm{cc}$ chloroform, $600 \mu \mathrm{l}$ methanol, and $600 \mu \mathrm{l} \mathrm{H}_{2} \mathrm{O}$ were added. The phases were separated as before. The upper phase containing deacylated phospholipids was removed and diluted 1:1, vol/vol with $10 \mathrm{mM}$ sodium tetraborate. The upper aqueous phase from this solution was removed after centrifugation and analyzed as below.

The deacylated phospholipid fractions were applied to $12 \times 0.75$ cm columns containing $1 \mathrm{cc}$ of anion exchange resin slurry (resin $\mathrm{H}_{2} \mathrm{O}$, $1: 1 ; \mathrm{vol} / \mathrm{vol}$ ). Serial elutions were performed with $10 \mathrm{cc}$ each of $5 \mathrm{mM}$ sodium tetraborate and $0.1 \mathrm{M}$ ammonium formate; $0.1 \mathrm{M}$ formic acid and $0.3 \mathrm{M}$ ammonium formate; and $0.1 \mathrm{M}$ formic acid and $0.75 \mathrm{M}$ ammonium formate eluting, respectively, glyceryl phosphatidyl inositol (GPI), GPI-4-monophosphate (GPI4P), and GPI-4,5-biphosphate (GPI4,5P 2 ).

The water-soluble inositide fraction was applied to similar columns and serially eluted with 10-cc aliquots of water, $0.25,0.1,0.2,0.5$, and $1.0 \mathrm{M}$ ammonium formate separating, respectively, inositol, GPI, inositol 1,2 cyclic phosphate (ICP), inositol-1-diphosphate (I1-P), inositol diphosphate (IDP), and inositol triphosphate (ITP). Both separations have been previously employed and validated $(20,21)$. Deacylated and watersoluble samples were collected in $800-\mu$ l aliquots and $1,600-\mu \mathrm{l}$ aliquots, respectively, and counted on a scintillation counter (LS 1801; Beckman Instruments, Inc.). To assess recovery, $\left[{ }^{3} \mathrm{H}\right]$ phosphatidol inositol (PI) was synthesized from the livers of mice by the method of Schacht (22) and separated by high performance liquid chromatography by the method of Yandrasitz et al. (23). Recovery of [ $\left.{ }^{3} \mathrm{H}\right] \mathrm{PI}$ added to cold cultures was $63 \%$ with $<0.3 \%$ of the label lost during deacylation and $11 \%$ lost during column chromatography.
Data presentation. Inositides are expressed as percent of incorporated label excluding free inositol. Data is expressed as the mean and standard error of the mean. Statistical analysis employed the paired $t$ test.

\section{Results}

Cell growth and morphology. Initial attempts were made to grow cells in $10 \%$ fetal calf serum and DME, as previously reported (6), but it was noted that fibroblast proliferation occurred after 7-10 d in culture (data not shown). No fibroblasts could be detected either by light or electron microscopy in cells grown in fully defined medium. Cells grown in this latter manner, however, plated less efficiently with only $20-30 \%$ adhering after 24 $\mathrm{h}$ as opposed to $60-70 \%$ grown in fetal calf serum. The use of inositol-free medium had no discernible effect on the ability of cells to adhere and reach confluency when compared with those grown in inositol replete medium. Cells typically took 5-6 d to reach confluency. The lack of $\mathrm{PGE}_{1}$ in the culture medium had no discernible effect on cell viability or morpholoy.

Fig. 1 displays light microscopic findings typical for confluent cultures. These cells were polygonal in appearance. No elongated cells, typical for differentiated fibroblasts seen in serum grown cells, were observed. Hemicysts, felt to represent active transport of solute from apical to basolateral surfaces (6), were commonly observed in confluent cultures when medium was not changed for $48 \mathrm{~h}$. Fig. 2 shows the electron microscopic appearance of these cells. Of note are the short microvillous projections, sparse mitochondria, and granular cytoplasm. Tight junctions were readily observed between cells. Cells grown past confluency typically did not remain adherent after 3-4 d.

cAMP and $i P G E_{2}$ production. The characterization of these cells was confirmed further by incubations with AVP and BK. Fig. 3 shows the levels of intracellular cAMP in cells exposed to $10^{-7} \mathrm{M}$ AVP and compared with time-marked control cells exposed to Krebs buffer alone.

In cells exposed to isobutylmethylxanthine (IBMX) $\left(10^{-4}\right.$ M), cAMP attained peak levels by $8 \mathrm{~min}$ and declined slowly through $60 \mathrm{~min}$ of incubation. Control cells did not demonstrate a comparable change. Peak cAMP attained a level of $203 \mathrm{fmol} /$ $\mu \mathrm{g}$ of cell protein.

Fig. 4 displays time-dependent changes in $\mathrm{iPGE}_{2}$ production in response to $\mathrm{BK}\left(10^{-7} \mathrm{M}\right)$. Here immunoreactive $\mathrm{PGE}_{2}$ showed a fourfold increase in concentration when measured over 60 min with detectable and statistically significant increases by 1 min. BK-exposed cells reached an PGE $_{2}$ concentration of 23.9 $\mathrm{ng} / \mathrm{mg}$ protein per $60 \mathrm{~min}$; mean control cells concentration was $4.9 \mathrm{ng} / \mathrm{mg}$ per protein per $60 \mathrm{~min}$.

Myo- $\left[2-{ }^{3} \mathrm{H}\right]$ inositol labeling and separation of phosphoinositols. $>90 \%$ of steady-state labeling occurred by $24 \mathrm{~h}$ in both aqueous and organic fractions with constant distribution between water and organically soluble counts (Fig. 5). Both lipid and water-soluble components were readily resolved by the chromatographic system employed (Fig. $6 A, B$ ). The amount of myo-[2- $\left.{ }^{3} \mathrm{H}\right]$ inositol extracted as free inositol composed $55-65 \%$ of the total phosphoinositides. The inositol containing lipid and water-soluble components, could be reliably detected and compared with one another as a percent of total incorporated counts. Table I expresses the distribution of these counts as a percent of total and as absolute numbers of counts per minute detected. Lipid-soluble inositides composed greater than $80 \%$ of the incorporated myo-[2- $\left.{ }^{3} \mathrm{H}\right]$ inositol. Inositol 1,4,5-triphosphate $\left(\mathrm{I} 1,4,5 \mathrm{P}_{3}\right)$ and inositol 1,4 diphosphate $\left(\mathrm{I} 1,4 \mathrm{P}_{2}\right)$ (although rep- 


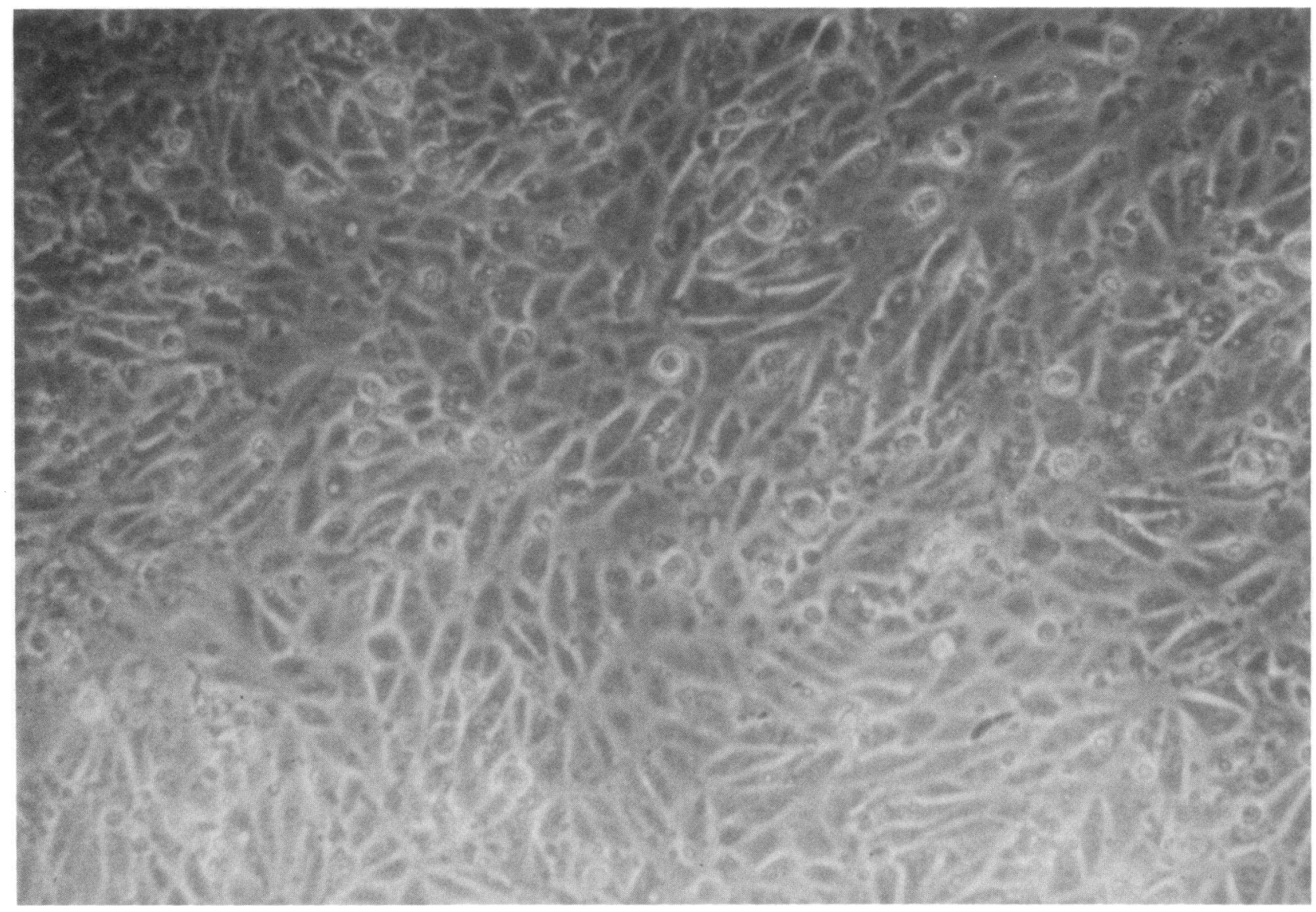

Figure 1. Phase-contrast photomicrograph of RPCT cells grown $7 \mathrm{~d}$ to confluence as a monolayer culture. $\times 200$.

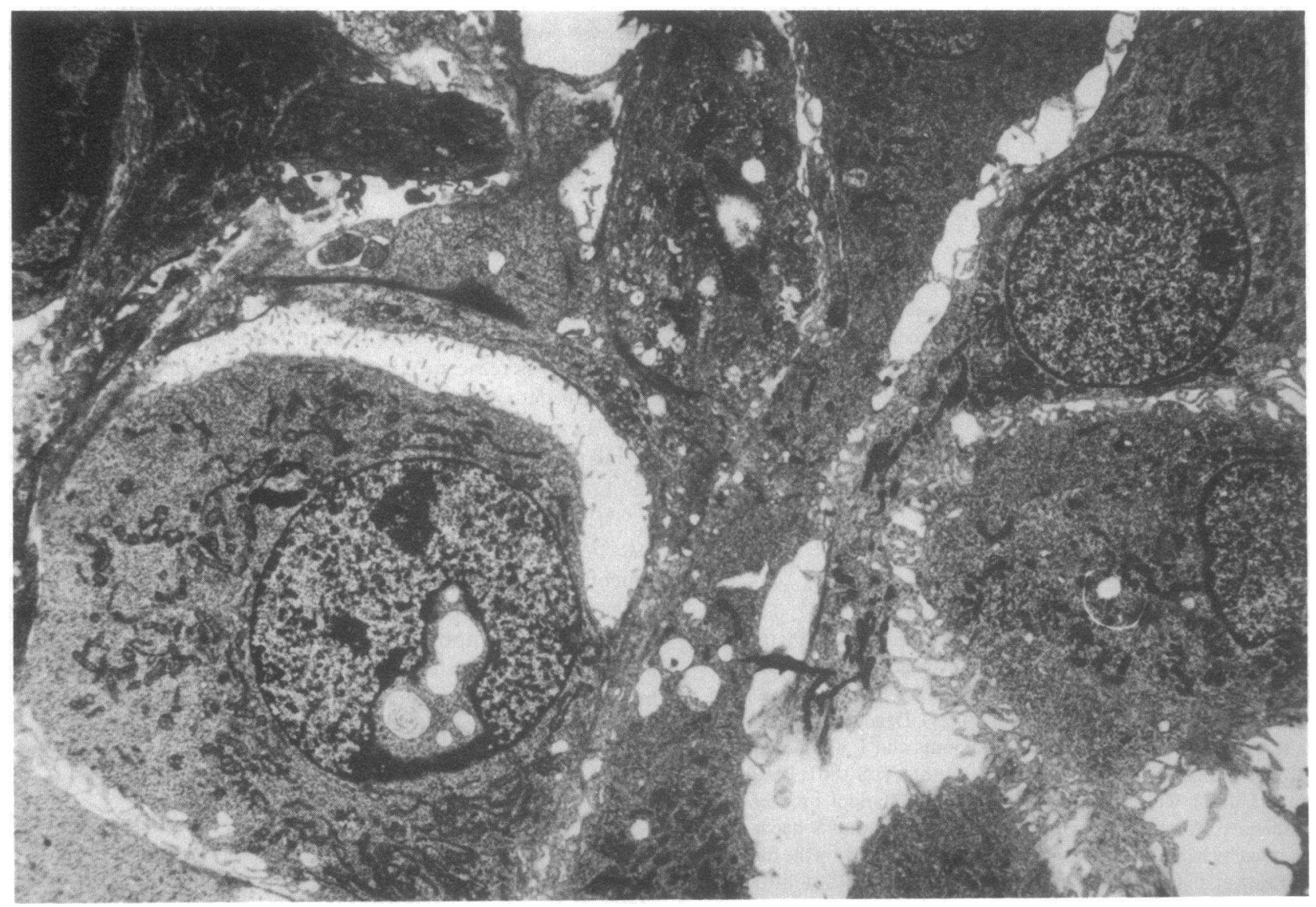

Figure. 2. Electron micrograph of RPCT cells fixed directly from 24-well culture dishes. $\times 5,400$. 


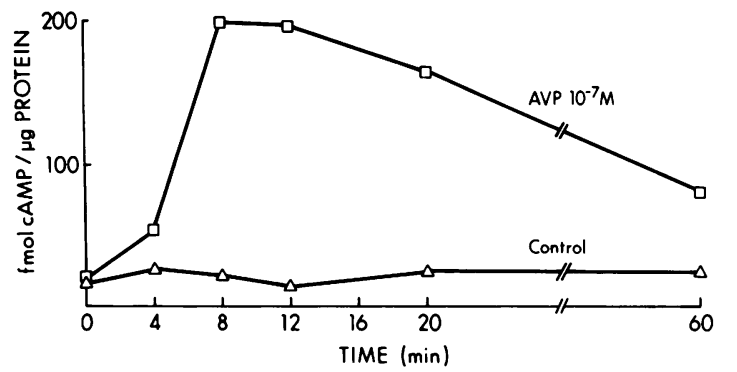

Figure 3. Time course of formation of intracellular cAMP by RPCT cells. (口), cells exposed to AVP $\left(10^{-7} \mathrm{M}\right)$ and IBMX $\left(10^{-4} \mathrm{M}\right)$ in Krebs buffer. $(\triangle)$, cells exposed to Krebs buffer alone. Values represent triplicate samples of three separate experiments. The SEM was $<10 \%$ of the total cAMP.

resenting $<3 \%$ of the total incorporation label) were reliably detected. Inositol cyclic phosphate was not readily detected under these extraction conditions.

Phosphoinositide changes in response to $\mathrm{BK}$. BK $\left(10^{-7} \mathrm{M}\right)$ induced rapid and pronounced changes in the distribution of labeled inositide components. Fig. 7 displays the change over time in lipid-soluble inositide labeling. The distribution of labeled PI4P increased markedly and rapidly within the first few seconds of stimulation. PI and phosphatidyl inositol 4,5 bisphosphate $\left(\mathrm{PI}, 5 \mathrm{P}_{2}\right)$, which overall represented a larger fraction of lipidincorporated myo-[2- $\left.{ }^{3} \mathrm{H}\right]$ inositol, demonstrated no such increase. Rather, an initial early fall in labeling was followed by a slow return toward control levels.

Inositol-containing moieties from the aqueous fraction, on the other hand, demonstrated marked early increases. Specifically, $\mathrm{I} 1,4, \mathrm{P}_{2}$ and $\mathrm{I} 1,4,5 \mathrm{P}_{3}$ labeling increased to levels greater than three times control. Of note was the observation that $\mathrm{I} 1,4,5 \mathrm{P}_{3}$ levels rose more rapidly than $\mathrm{I} 1,4, \mathrm{P}_{2}$ levels. The peak increase of $11,4,5 \mathrm{P}_{3}$ was $225 \%$ at $5 \mathrm{~s}$, while the peak of $11,4 \mathrm{P}_{2}$ was $223 \%$ at $15 \mathrm{~s}$. The pattern of GPI was similar to the free polyphosphoinositols. I1P levels, however, increased less markedly and did not attain statistical significance with the number of samples employed. Dose-dependent changes in $11,4,5 \mathrm{P}_{3}$ following $15 \mathrm{~s}$ of BK incubation are displayed in Fig. 9. Peak I1,4,5 $\mathrm{P}_{3}$ labeling occurred at $10^{-7} \mathrm{BK}$ with an $\mathrm{ED}_{50}$ between $10^{-7}$ and $10^{-9} \mathrm{M}$ BK.

\section{Discussion}

The present investigation supports the view that RPCT cells demonstrate active phosphatidyl inositol turnover in response to BK. The study also demonstrates that BK-stimulated inositide

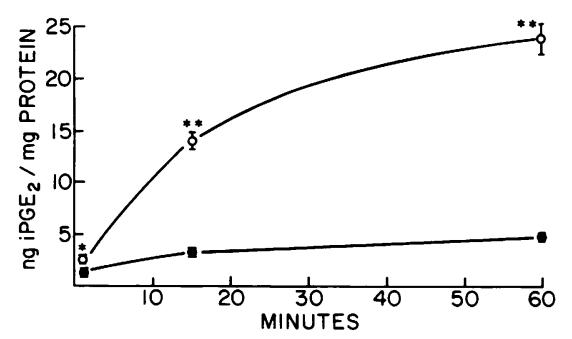

Figure 4. Immunoreactive $\mathrm{PGE}_{2}$ in RPCT cells exposed to Krebs buffer (control, closed circles) or BK $\left(10^{-7} \mathrm{M}\right.$, open circles) as a function of time. Values are expressed as \pm SEM. $\left({ }^{*}\right)$ denotes $P<0.01$; $\left({ }^{* *}\right), P<0.001$.

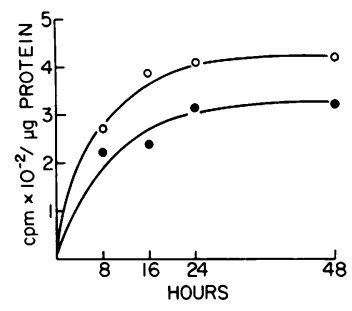

Figure 5. Total aqueous (0) and lipidextractable (๑) myo- $\left[2-{ }^{3} \mathrm{H}\right]$ inositol per well. Cells were incubated for varying lengths of time with $1 \mu \mathrm{Ci}$ myo-[2${ }^{3} \mathrm{H}$ ]inositol per well. After the incubation, cells were extracted as described in Methods but counted before exchange chromatography. Data represent the mean of duplicate samples of three separate experiments.

turnover in distal renal epithelia is associated with increased labeling of free polyphosphoinositides. Both of these observations have not been previously reported.

Because renal tissue is heterogeneous and multifunctional, and because there exist other cells within the renal medulla and papilla capable of responding to AVP and BK in similar manners, it was important to characterize the cultured material as RPCT cells. Fibroblasts, for example, are capable of elaborating PGs in response to $\mathrm{BK}$ and occur in large numbers in papillary tissue (24-26). Medullary renal tissue elaborates PGs in response to
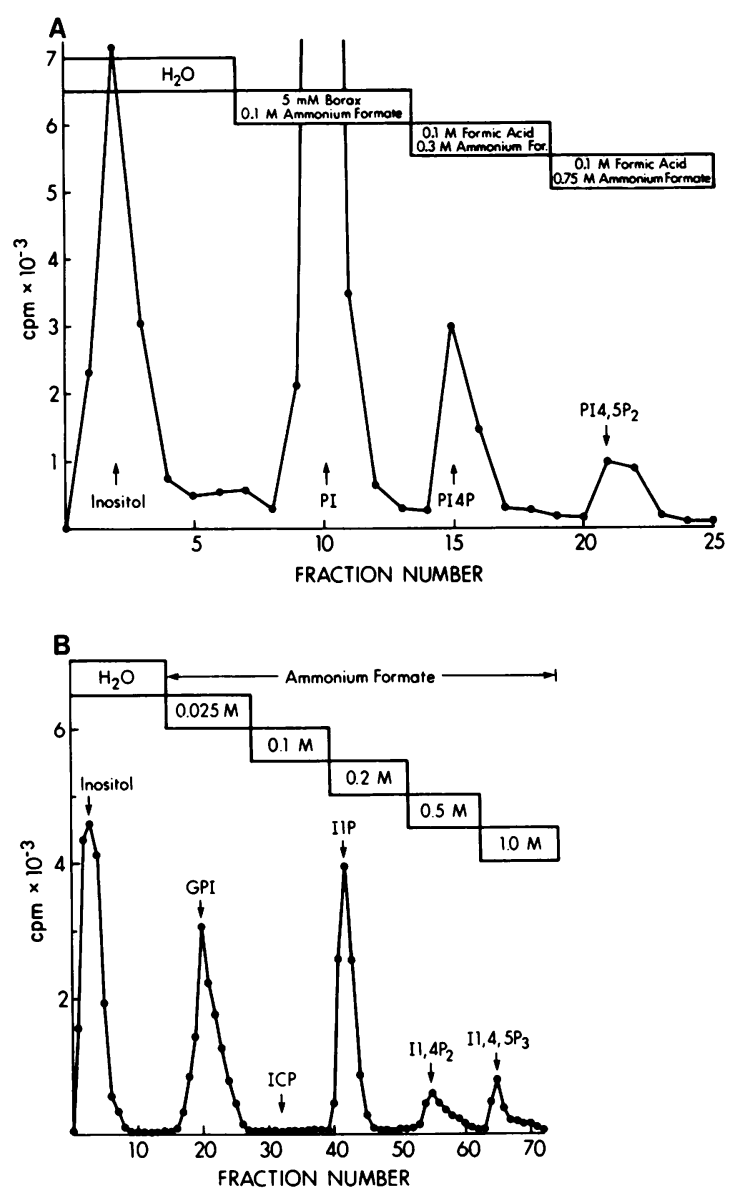

Figure 6. $(A)$ Chromatographic resolution of deacylated myo-[2${ }^{3} \mathrm{H}$ ]inositol, containing lipids. Free inositol, representing $<1 \%$ of the initially added label, was eluted with water alone. PI eluted as GPI; PI4P eluted as GPI4P; and PI4,5P $\mathrm{P}_{2}$ eluted as GPI4,5P $\mathrm{P}_{2}$ ( $B$ ) Chromatographic resolution of water soluble inositides. The chromatographs displayed were obtained from separate samples and do not represent the absolute distribution of total counts between lipid and water soluble inositides. 
Table I. Incorporated $\left[{ }^{3} \mathrm{H}\right]$ Inositol

\begin{tabular}{lcl}
\hline Lipid class & Culture well & Percent distribution \\
\hline & $c p m$ & \\
GPI & $3,663 \pm 809$ & $(0.061)$ \\
IIP & $4,389 \pm 817$ & $(0.074)$ \\
I1,4P & $984 \pm 218$ & $(0.017)$ \\
I1,4,5P & $967 \pm 194$ & $(0.016)$ \\
PI & $35,768 \pm 4,729$ & $(0.600)$ \\
PI4P & $9,870 \pm 1,938$ & $(0.166)$ \\
PI4,5P & $3,922 \pm 954$ & $(0.066)$ \\
\end{tabular}

AVP via a cAMP-independent mechanism (5). Renal medullary interstitial cells produce $\mathrm{PGE}_{2}$ in response to AVP, angiotensin II, and BK $(27,28)$.

The characterization of these cells is most consistent with RPCT cells. The morphological appearance by electron microscopy demonstrates a homogenous cell population with junctional complexes and microvillous-like structures. The lipidladen vacuoles, typical for medullary interstitial cells (25), were not seen. Cells were grown without serum, shown previously to be an important contributant to fibroblast growth (16). Finally, cells responded to AVP and BK with elevations in CAMP and iPGE $_{2}$, quantitatively and temporally consistent with previous observations $(6,29)$. The observation that RPCT cells can be maintained in inositol-free medium appears to be new.

This study provides two observations that support the association between PI turnover and $\mathrm{PGE}_{2}$ elaboration in RPCT cells. First, PI turnover, and specifically $\mathrm{I} 1,4,5 \mathrm{P}_{3}$ labeling, is temporally consistent with $\mathrm{PGE}_{2}$ production. Second, the dose response curve and specifically the $\mathrm{ED}_{50}$ for $\mathrm{BK}$ elaboration of I1,4,5 $\mathrm{P}_{3}$ parallels closely that demonstrated by Grenier et al. for BK-stimulated $\mathrm{PGE}_{2}$ production.

Increased labeling of free inositol polyphosphates with hormonal or divalent cation ionophore stimulation has now been

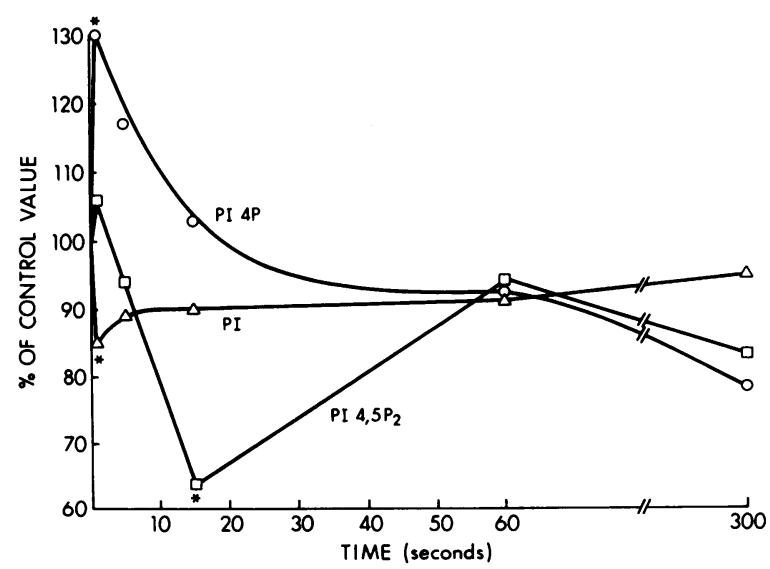

Figure 7. Time-dependent changes in myo- $\left[2-{ }^{3} \mathrm{H}\right]$ inositol containing lipids. Data is expressed as the percent change in distribution of myo$\left[2-{ }^{3} \mathrm{H}\right]$ inositol from control values. $(\Delta), \mathrm{PI}$; (O), PI4P; (口), PI4,5P $\mathbf{2}_{2}$ Time points represent 1-, 5-, 15-, 60-, and 300-s incubations. The data displayed represent the mean change in distribution from four separate experiments. The SEM is $<30 \%$ for all time points. $\left({ }^{*}\right)$ denotes $P$ $<0.05$.

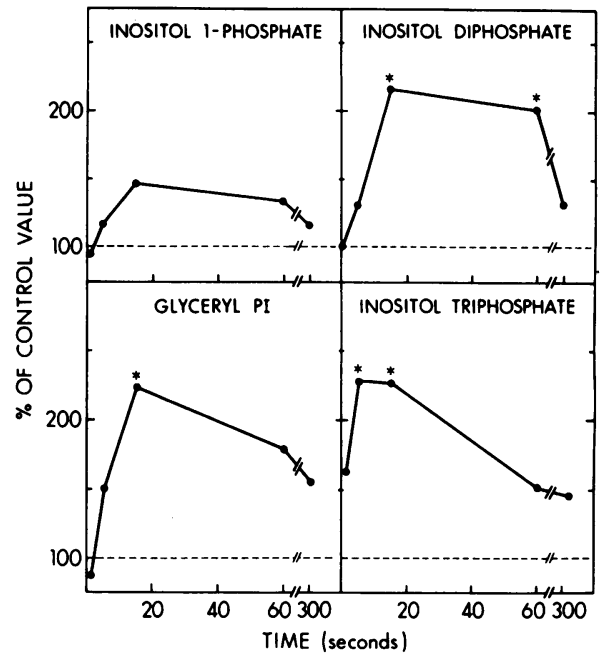

Figure 8. Time-dependent changes in myo- $\left[2-{ }^{3} \mathrm{H}\right]$ inositol water soluble inositides. Data represent the percent change in the distribution of myo- $\left[2-{ }^{3} \mathrm{H}\right]$ inositol from control values. Time points represent 1,5 , 15,60 , and $300 \mathrm{~s}$. The data represent the mean change in distribution of four separate experiments. The SEM is $<30 \%$ for all time points. $\left({ }^{*}\right)$ denotes $P<0.01$.

demonstrated in several other systems, including macrophages (20), platelets (30), salivary glands (31), and pituitary cells (30). It has not been reported previously in kidney and not in response to BK. The pattern of labeling of lipid-soluble components is consistent with a shuttling of PI to PI4P and PI4,5 $\mathrm{P}_{2}$, perhaps to serve as substrates for phospholipase $C$ action. Similar changes in PI4P and PI4,5 $\mathrm{P}_{2}$ during stimulation have been reported elsewhere $(13,20)$. Whether the tendency for $I 1,4,5 \mathrm{P}_{3}$ to rise before $\mathrm{I}, 4 \mathrm{P}_{2}$ represents the result of a specific phosphatase acting upon I1,4,5 $\mathrm{P}_{3}$ or the action of phospholipase $\mathrm{C}$ upon PI4P remains unclear given the limited sensitivity of these methods as well as the current inability to measure directly the mass of the inositol polyphosphates. Similarly, whether the time required for $11,4,5 \mathrm{P}_{3}$ to rise is indicative of the kinetics of phospholipase $\mathrm{C}$ action or simply the finite time required for $\mathrm{BK}$ to diffuse toward and bind to the cell surface remains unanswered. The apparent precedent rise in $11,4,5 \mathrm{P}_{3}$ compared with $I 1,4 \mathrm{P}_{2}$, however, is not consistent with the recent suggestion that hormonal stimulation involves a PI4P-specific phospholipase $\mathrm{C}$ following formation of PI4P from PI4,5, $\mathrm{P}_{2}$ (32).

The apparent reversibility in levels of the inositol polyphosphates may represent the result of one or more phenomena. These would include, for example, substrate depletion, receptor

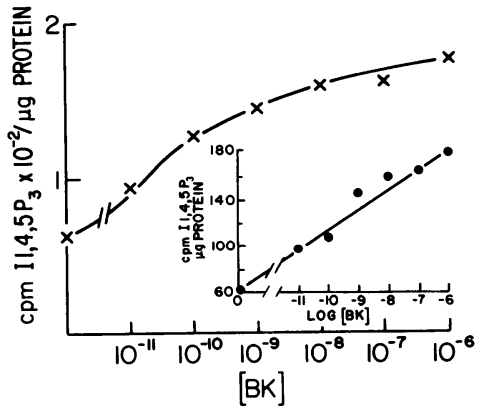

Figure 9. Dose-dependent changes in myo-[2${ }^{3} \mathrm{H}$ ]inositol labeled $\mathrm{I} 1,4,5, \mathrm{P}_{3}$ in response to $\mathrm{BK}$. $\mathrm{ED}_{\mathbf{}}$ is $5 \times 10^{9} \mathrm{M}$. Each point represents the mean of three experiments. 
desensitisation (which may occur within a few minutes) (33), or the action of a kininase that degrades the effector (11), or another, as yet undefined, cellular mechanism. This observation is, however, consistent with previous reports demonstrating that the most rapid increase in $\mathrm{iPGE}_{2}$ release occurs within the first minutes of stimulation (13) even in the presence of continued BK exposure.

This investigation does not address two additional questions. First, what is the substrate for arachidonic acid release, diacylglycerol, or PI? Hong and co-workers (34) suggest that lysophosphatidyl inositol is the byproduct of arachidonic acid release via $B K$-induced phospholipase $A_{2}$ action in fibroblasts. As evidence they show no rise in free inositol phosphates in cells so stimulated. If this interpretation is correct, their report coupled with the data presented here suggest that the same effector, namely BK, in different cells may transduce its signal via the PI cycle, but via different pathways.

A second, unaddressed issue concerns the functional roles of PI turnover in RPCT cells. It is probable that inositol polyphosphate release serves a role separate from that of diacylglycerol, the other product of phospholipase $\mathrm{C}$ action. The main consideration for such a role includes changes in intracellular calcium. In support for such an effect being operative in RPCT cells, it has been shown that the divalent ionophore A23187 can induce $\mathrm{PGE}_{2}$ release (6). $\mathrm{I} 1,4,5 \mathrm{P}_{3}$ has been suggested to induce $\mathrm{Ca}^{2+}$ mobilization in both saponin permeabilized liver cells (35) and pancreatic cells (36). Intracellular release of free $\mathrm{Ca}^{2+}$ may therefore be an important factor in $\mathrm{PGE}_{2}$ elaboration in RPCT cells. A second, less substantiated role for inositol polyphosphates may involve the induction of greater membrane fluidity (37). Discerning the specific role of such effects in $\mathrm{PGE}_{2}$ elaboration, ion or water transport, or modulation of vasopressin action requires further study.

These biochemical considerations provide potential direction for the further study of the now documented antagonism of kinins and vasopressin (38). Calcium has been demonstrated to play an important role in arachidonate release and thus in $\mathrm{PGE}_{2}$ elaboration. $\mathrm{PGE}_{2}$ has been reported to inhibit cAMP formation at physiologic levels (10). Calcium ion, however, may play an important inhibitory role apart from that of prostaglandin formation. In nonmuscle cells for example, calcium may regulate the arrangement and organization of cytoskeletal elements (39). Because cAMP-dependent and calcium-dependent protein kinases have been described in association with cytoskeletal proteins in other tissues, it is not unreasonable to suspect that these kinases may play a role in distal tubular epithelia and specifically in sodium and water transport $(40,41)$. Support for this view rests on the ability of bradykinin to mobilize intracellular calcium. Preliminary data in Quin 2-labeled papillary collecting tubule cells support this observation (unpublished observations).

In summary, RPCT cells can be grown in fully defined media and labeled with sufficiently high activity to study changes in free polyphosphoinositols. $\mathrm{BK}$, a potent effector of $\mathrm{PGE}_{2}$ release, induces marked changes in PI turnover with increased labeling of free polyphosphoinositols.

\section{Acknowledgments}

This work was supported by Public Health Services awards AM30542 and AM09976. Dr. Morrison is an Established Investigator of the American Heart Association.

\section{References}

1. Omachi, R. S., D. E. Robbie, J. S. Handler, and J. Orloff. 1974. Effects of ADH and other agents on cyclic AMP accumulation in toad bladder epithelium. Am. J. Physiol. 226:1152-1157.

2. Torikai, S., and K. Kurokawa. 1983. Effect of $\mathrm{PGE}_{2}$ on vasopressindependent cell cAMP in isolated single nephron segments. Am. J. Physiol. 245:F58-F66.

3. Lum, G. M., G. A. Aisenbrey, M. J. Dunn, T. Berl, R. W. Schrier, and K. M. McDonald. 1977. In vivo effect of indomethacin to potentiate the renal medullary cyclic AMP response to vasopressin. J. Clin. Invest. 59:8-13.

4. Edwards, R. M., B. A. Jackson, and T. P. Dousa. 1981. ADHsensitive cAMP system in papillary collecting duct: effect of osmolality and PGE 2 . Am. J. Physiol. 240:F311-F318.

5. Craven, P. A., and F. R. DeRubertis. 1981. Effects of vasopressin and urea on $\mathrm{Ca}^{2+}$-calmodulin-dependent renal prostaglandin E. Am. J. Physiol. 241:F649-F658.

6. Grenier, F. C., T. E. Rollins, and W. L. Smith. 1981. Kinin-induced prostaglandin synthesis by renal papillary collecting tubule cells in culture. Am. J. Physiol. 241:F94-F104.

7. Furtado, M. 1971. Inhibition of the permeability response to vasopressin and oxytocin in the toad bladder. J. Membr. Biol. 4:165-178.

8. Cuthbert, A. W., and H. S. Margolius. 1981. Kinin effects on electrolyte transport in rat colon. J. Physiol. 319:45P.

9. Manning, D. C., S. H. Synder, J. F. Kachur, R. J. Miller, and M. Field. 1982. Bradykinin receptor-mediated chloride secretion in intestinal function. Nature (Lond.). 299:256-259.

10. Garcia-Perez, A., and W. L. Smith. 1984. Apical-basolateral membrane asymmetry in canine cortical collecting tubule cells. Bradykinin, arginine vasopressin, prostaglandin $\mathrm{E}_{2}$ interrelationships. J. Clin. Invest. 74:63-74.

11. Roscher, A. A., V. C. Manganiello, C. L. Jelsema, and J. Moss. 1984. Autoregulation of bradykinin receptors and bradykinin-induced prostacyclin formation in human fibroblasts. J. Clin. Invest. 74:552558.

12. Bell, R. L., N. L. Baenziger, and P. W. Majerus. 1980. Bradykininstimulated release of arachidonate from phosphatidyl inositol in mouse fibrosarcoma cells. Prostaglandins. 20:269-274.

13. Benabe, J. E., L. A. Spry, and A. R. Morrison. 1982. Effects of angiotensin II on phosphatidyl inositol and polyphosphatidylinositol turnover in rat kidney. J. Biol. Chem. 257:7430-7434.

14. Meltzer, V., S. Weinreb, E. Bellorin-Font, and K. A. Hruska. 1982. Parathyroid hormone stimulation of renal phosphoinositide metabolism is a cyclic nucleotide-independent effect. Biochim. Biophys. Acta. 712:258-267.

15. Taub, M., L. Chuman, M. H. Saier, and G. Sato. 1979. Growth of Madin-Darby canine kidney epithelial cell (MDCK) line in hormonesupplemented, serum-free medium. Proc. Natl. Acad. Sci. USA. 76:3338.

16. Jefferson, D. M., M. H. Cobb, J. F. Gennaro, and W. N. Scott. 1980. Transporting renal epithelium: culture in hormonally-defined serum-free medium. Science (Wash. DC). 210:912-914.

17. Steiner, A. L., A. S. Pagliara, L. R. Chase, and D. M. Kipnis. 1972. Radioimmunoassay for cyclic nucleotides. I. Adenosine 2',5'monophosphate and guanosine $3^{\prime}, 5^{\prime}$-monophosphate in mammalian tissues and body fluids. J. Biol. Chem. 247:1114.

18. Tamayo, J., E. Bellorin-Font, G. Sicard, O. Anderson, and K. J. Martin. 1982. Desensitization to parathyroid hormone in the isolated perfused canine kidney: reversal of altered receptor-adenylate cyclase system by guanosine triphosphate in vitro. Endocrinology. 111:13111317.

19. Lowry, O. H., N. J. Rosebrough, A. L. Farr, and R. J. Randall. 1951. Protein measurement with the Folin phenol reagent. J. Biol. Chem. 193:265-275.

20. Emilsson, A., and R. Sundler. 1984. Differential activation of phosphatidylinositol deacylation and pathway via diphosphoinositide in macrophages responding to zymosan and ionophore A23187. J. Biol. Chem. 259:3111-3116. 
21. Rhodes, D., V. Prpić, J. H. Exton, and P. F. Blackmore. 1983. Stimulation of phosphatidylinositol 4,5-bisphosphate hydrolysis in hepatocytes by vasopressin. J. Biol. Chem. 258:2770-2773.

22. Schacht, J. 1981. Extraction and purification of polyphosphoinositides. Methods Enzymol. 72:626-631.

23. Yandrasitz, J. R., G. Berry, and S. Segal. 1981. High performance liquid chromatography of phospholipids with UV detection. J. Chromatogr. 225:319-328.

24. McGiff, J. C., H. D. Itskovitz, N. A. Terrango, and P. Y. K. Wong. 1976. Modulation and mediation of the action of the renal kallikrein-kinin system by prostaglandins. Fed. Proc. 35:175-180.

25. Hong, S. C., and L. Levine. 1976. Stimulation of prostaglandin synthesis by bradykinin and thrombin and their mechanisms of action on MC5-S fibroblasts. J. Biol. Chem. 251:5814-5816.

26. Fahey, J. V., C. P. Ciosek, Jr., and D. S. Newcombe. 1977. Human synovial fibroblasts. The relationships between cyclic AMP, bradykinin and prostaglandins. Agents Actions. 7:255-264.

27. Muirhead, E. E., G. Germain, B. E. Leach, J. A. Pitcock, P. Stephenson, B. Brooks, W. L. Brosins, E. G. Daniels, and J. W. Hinman 1972. Production of renomedullary prostaglandins by renomedullary interstitial cells grown in tissue culture. Circ. Res. 30/31(Suppl. 2):II161-II-172.

28. Zusman, R. M., and H. R. Keiser. 1977. Prostaglandin biosynthesis by rabbit renomedullary interstitial cells in tissue culture: stimulation by angiotensin II, bradykinin, and arginine vasopressin. J. Clin. Invest. 60:215-223.

29. Pugliese, F., M. Sato, S. Williams, M. Aikawa, A. Hassid, and M. Dunn. 1983. Rabbit and rat renal papillary collecting tubule cells in culture: the interactions of arginine vasopressin, prostaglandins, and cyclic AMP. Adv. Prostaglandin Thromboxane Leukotriene Res. 11:517-523.

30. Agranoff, B. W., P. Murphy, and E. B. Seguin. 1983. Thrombininduced phosphodiesteratic cleavage of phosphatidylinositol bisphosphate in human platelets. J. Biol. Chem. 258:2076-2078.
31. Berridge, M. J. 1983. Rapid accumulation of inositol triphosphate reveals that agonists hydrolyse polyphosphoinositides instead of phosphatidylinositol. Biochem. J. 212:849-858.

32. Kolesnek, R. N., and M. C. Gershengorn. $1984 . \mathrm{Ca}^{2+}$ ionophores affect phosphoinositide metabolism differently than thyrotropin-releasing hormone in $\mathrm{GH}_{3}$ pituitary cells. J. Biol. Chem. 259:9514-9519.

33. Roscher, A. A., V. C. Manganiello, C. L. Jelscma, and J. Moss. 1984. Autoregulation of bradykinin receptors and bradykinin-induced prostacyclin formation in human fibroblasts. J. Clin. Invest. 74:552558.

34. Hong, S. L., and D. Deykin. 1981. The activation of phosphatidylinositol-hydrolyzing phospholipase $\mathrm{A}_{\mathbf{2}}$ during prostaglandin synthesis in transformed mouse BALB/3T3 cells. J. Biol. Chem. 256:5215-5219.

35. Joseph, S. K., A. P. Thomas, R. J. Williams, R. F. Irvine, and J. R. Williamson. 1984. Myo-inositol 1,4,5-triphosphate: a second messenger for the hormonal mobilization of intracellular $\mathrm{Ca}^{2+}$ in liver. $J$. Biol. Chem. 251:3077-3081.

36. Streb, H., R. F. Irvine, M. J. Berridge, and I. Schulz. 1983. Release of $\mathrm{Ca}^{2+}$ from a nonmitochondrial intracellular store in pancreatic acinar cells by inositol-1,4,5-triphosphate. Nature (Lond.). 306:67-69.

37. Sheetz, M. P., P. Fibbroviello, and D. E. Koppel. 1982. Triphosphoinositide increase glycoprotein lateral mobility in erythrocyte membranes. Nature (Lond.). 296:91-93.

38. Schuster, V. L., J. P. Kokko, and H. R. Jacobson. 1984. Interaction of lysyl-bradykinin and antidiuretic hormone in the rabbit cortical collecting tubule. J. Clin. Invest. 73:1659-1667.

39. Craig, S. W., and T. D. Pollard. 1982. Actin-binding proteins. Trends Biochem. Sci. 7:88-92.

40. Vallee, R. B., M. J. DiBartolomeis, and W. D. Theurkauf. 1981. A protein kinase bound to the projection portion of MAP 2. J. Cell Biol. 90:568-576.

41. Burn, P., A. Rotman, R. K. Meyer, and M. M. Burger. 1985. Diacylglycerol in large $\alpha$-actin/actin complexes and in the cytoskeleton of activated platelets. Nature (Lond.). 314:469-472. 